УДК 374:373.3011.3-051(477.86)

DOI:

Наталія Басараб, аспірантка кафедри педагогіки та освітнього менеджменту імені Богдана Ступарика Прикарпатського національного університету імені Василя Стефаника

\title{
ПОКРАЩЕННЯ ПОЛІТИК РІВНОГО ДОСТУПУ ДО ОСВІТНІХ МОЖЛИВОСТЕЙ ВЧИТЕЛІВ ПОЧАТКОВОЇ ШКОЛИ ТЕРИТОРІАЛЬНИХ ГРОМАД ІВАНО-ФРАНКІВЩИНИ
}

Ключова ідея нашого дослідження - виявити шляхи політик рівного доступу до освітніх можливостей вчителів початкової школи територіальних громад Івано-Франківщини в умовах модернізації системи післядипломної освіти через позиції відповідей на запитання про узгодження суперечності між реальним змістом педагогічної освіти, вимогами школи та викликами держави.

Завдяки участі в різних формах навчання, творчому підходу до викладання, опрачюванню наукової та методичної літератури, власним педагогічним пошукам, самоосвіті - педагоги стають ініціаторами й активними учасниками творчих змін в шкільній реальності. Зі свого боку, кожен причетний до викликів сучасної освіти повинен не тільки визнавати важливість професії вчителя початкової школи, але й сприяти та підтримувати його діяльність. Відтак пропонуємо рекомендації, які адресовані трьом групам установ та організацій задля ефективного їх впровадження на регіональному рівні: по-перше, відділу освіти, директорам шкіл; по-друге, закладам підвищення кваліфікації; по-третє, методичним об 'єднанням, иколам передового досвіду.

Ключові слова: післядипломна педагогічна освіта; підвищення кваліфікачії вчителів; початкова школа; доступ до освіти; самоосвіта.

Jim. 23.

Nataliia Basarab, Postgraduate Students of the Pedagogy and Educational Management Department named after Bohdan Stuparyk Vasyl Stefanyk Precarpathian National University

\section{IMPROVING OF POLICIES OF EQUALACCESS TO THE EDUCATIONAL OPPORTUNITIES OF PRIMARY SCHOOL TEACHERS OF TERRITORIAL COMMUNITIES OF IVANO-FRANKIVSK REGION}

The key idea of our study is to identify the ways of equal access to educational opportunities for primary school teachers in Ivano-Frankivsk region in the modernization of postgraduate education through positions of answers to questions about reconciling the contradictions between the real content of pedagogical education, school requirements and state challenges.

Teachers are a special group of professionals who improve their skills not for the sake of career growth or the desire to meet the requirements of the labor market. They are motivated to learn by more altruistic things: the school's attitude towards professional growth, a sense of responsibility for student learning, the desire to help each child master modern knowledge and skills, and to enjoy their work, respect and pride in their profession. In view of this, we understand that a teacher who teaches not only the mind but also the heart needs to be able to improve their own professional level, to form modern competencies. Pedagogical activity cannot be set within certain instructional frameworks, because only with the establishment of professional freedom can the effective organization of professional growth be possible.

Through participation in various forms of learning, creative approach to teaching, development of scientific and methodological literature, their own pedagogical research, self-education - teachers become initiators and active participants in creative changes in school reality. In turn, everyone involved in the challenges of modern education must not only recognize the importance of the primary school teacher profession, but also promote and support its work. Therefore, we offer recommendations addressed to three groups of institutions and organizations for their effective implementation at the regional level: first, the Department of Education, school principals; secondly, training institutions; third, methodological associations, schools of excellence.

Keywords: postgraduate pedagogical education; teacher training; Elementary School; access to education; self-education.

П остановка проблеми. На сьогодні післядипломна освіта вчителів початкових шкілстала експериментальним майданчиком умасштабі країни для відпрацювання нових за демократичним змістом методик навчання. 3 одного боку, освіта виступає гарантом забезпечення потреб держави у висококваліфікованих, конкурентоспроможних, різнобічно розвинених 


\section{ПОКРАЩЕННЯ ПОЛІТИК РІВНОГО ДОСТУПУ ДО ОСВІТНІХ МОЖЛИВОСТЕЙ ВЧИТЕЛІВ ПОЧАТКОВОӤ ШКОЛИ ТЕРИТОРІАЛЬНИХ ГРОМАД ІВАНО-ФРАНКІВЩИНИ}

фахівцях. А з іншого - $є$ засобом розвитку індивідуального, особистісного в людині. Для дорослої людини, дипломованого педагога, розвиток особистісних функцій тісно пов'язаний iз самоутвердженням, самоповагою, баченням своїх життєвих та професійних перспектив, усвідомлення своєї суспільної цінності та значущості, де присутня неодмінна участь підвищення професійної кваліфікації у системі післядипломної освіти [9]. Не можна забувати й те, що вчительська праця є надзвичайно специфічною, особливою, вимагає досить бережливого ставлення і прискіпливої кваліфікаційної уваги для подальшого розвитку шкільної, педагогічної та післядипломної освіти вчителів. Розуміємо, що забезпечення потреби удосконалення політик рівного доступу до освітніх можливостей вчителів початкової школи територіальних громад Івано-Франківщини, належна організація підвищення рівня освіти педагогів неможливі без застосування інструментів зворотного зв'язку, попереднього вивчення потреб та узгодження отриманих відповідей з управлінськими кроками посадовців, можливостями кваліфікаційної підготовки, змістом навчальних програм тощо.

3 огляду актуальності та особливостей освітнього процесу на регіональному рівні ми обрали саме таку тему. Отож, предмет дослідження - удосконалення політик рівного доступу до освітніх можливостей; об'єкт вчителі початкової школи територіальних громад Івано-Франківщини.

Цільова аудиторія - органи влади (відділ освіти), заклади підвищення кваліфікації, школи передового досвіду, дирекція школи, методичні об'єднання, вчителі початкових класів.

Проблема дослідження. Розв'язання суперечності між реальним змістом педагогічної освіти, вимогами школи та викликами держави.

Дослідницьке питання. Як поліпшити (урівноважити) доступ до освітніх можливостей вчителів початкової школи територіальних громад Івано-Франківщини?

Методологія. Задля розв'язання поставленого дослідницького питання вважаємо доречним застосування переважно якісної стратегії дослідження. А саме: по-перше, кабінетного дослідження (аналіз джерельної бази та вторинний аналіз раніше проведених досліджень 3 проблематики); по-друге, фокус-групових дискусій (ми плануємо провести 2 фокус-групи, а саме: 1) із працівниками шкіл; 2) управлінцями освітньої галузі Прикарпаття разом з надавачами освітніх послуг післядипломної підготовки).
Що стосується джерельної бази, ми опрацювали статті української періодики, наукові праці сучасних вчених, які вивчали питання освіти вчителів початкової школи (монографії, дисертації, автореферати, матеріали конференцій) С. Бачинської [2], I. Дзежговської [4], Н. Клокар [6], Н. Матвеєвої [8], І. Ніколаєску [12], Н. Носовець [13], В. Олійника [15], В. Приймакової [16], Р. Скульського [20], А. Терещенко [22], Л. Тимчук [23] та інших. Науковці своїми працями сприяли ефективному розвитку післядипломної освіти вчителів, глибинній змістовій і якісній ії перебудові, модернізації форм та методів підвищення кваліфікації. Зростання рівня освіти педагогів пов'язується 3 надією підвищити ефективність освіти загалом.

Щодо проведених досліджень, ознайомилися 3 декількома 3 тих, які вивчали питання розвитку і реформування освіти України та були у вільному доступі:

- Стратегія реформування освіти в Україні: Рекомендації з освітньої політики (2003) [21]. Проводилося - за підтримки Програми розвитку Організації Об'єднаних Націй, Міжнародного фонду "Відродження", Інституту відкритого суспільства (Будапешт). Це була перша спроба комплексного підходу до визначення та розроблення варіантів розв'язання проблем освітнього сектора України відповідно до вимог, які висуває людству XXI ст.

- Популярна економіка: моніторинг реформ (2013) [18]. Проводилося - на базі Світового банку, за підтримки Інституту відкритого суспільства. Констатовано, що упродовж двадцяти років незалежності система української освіти практично не реформувалася. Виявлено, що недоліками цієї системи залишаються обмежена автономія закладів освіти, неефективність державного фінансування та корупція.

- Моніторинг інтеграції української системи вищої освіти в Свропейський простір вищої освіти та наукового дослідження (2014) [10]. Проводилося - Міжнародним Благодійним Фондом “Міжнародний Фонд досліджень освітньої політики”. Показано можливості просування гнучких освітніх траєкторій, у тому числі, вечірньої, заочної, дистанційної форм навчання та екстернату. Запропоновано власну методику розрахунку частки осіб, що здобувають вищу освіту одразу після завершення середньої освіти.

- Навчати й навчатися: як і куди зростати українському вчительству (2018) [11]. Проводилося - ГО "ЕdСатр Україна" разом із Міністерством освіти і науки України. Виявлено, що 79 \% українських вчителів вважають, що систему підвищення кваліфікації педагогів потрібно 


\section{ПОКРАЩЕННЯ ПОЛТТИК РІВНОГО ДОСТУПУ ДО ОСВІТНІХ МОЖЛИВОСТЕЙ ВЧИТЕЛІВ ПОЧАТКОВОЇ ШКОЛИ ТЕРИТОРІАЛЬНИХ ГРОМАД ІВАНО-ФРАНКІВЩИНИ}

реформувати й робити це має Міністерство освіти і науки України.

- Потреби вчителів у підвищенні фахового рівня з питань використання цифрових засобів та ІКТ в умовах карантину (2020) [14]. Проводилося Інститутом інформаційних технологій і засобів навчання Національної академії педагогічних наук України. Досліджено, що вчителі є основними рушіями та агентами здійснення дистанційних заходів в умовах карантину: саме вони навчають онлайн, консультують батьків, здійснюють самоосвіту для підвищення свого фахового рівня. Окреслено рекомендації щодо підвищення фахового рівня вчителів з питань використання IКТ та здійснення дистанційного навчання в умовах карантину.

- Training Assessment Project, дослідження щодо забезпечення підготовки педагогічних працівників (2021) [3]. Проводиться - МОН України спільно з Українським інститутом розвитку освіти за підтримки Групи Світового банку. Це дослідження стане важливим джерелом даних для формування доказової освітньої політики щодо підготовки та професійного розвитку, мотивації педагогічних працівників у контексті імплементації реформи “Нова українська школа” та інших реформ у сфері освіти.

Проаналізувавши вищеперелічені дослідження, виникає питання - чи вивчалися потреби, запити працівників освітньої інфраструктури регіонів $[1$, 254-256], особливо на теренах новоутворених територіальних громад? Пошук відповідей на ці та інші запитання, на наше переконання, наразі, залишається управлінським завданням майбутнього. Адже практично відсутні системні, комплексні дослідження оцінювання ефективності впровадження освітньої політики на місцевому piвнi.

Наступний етап нашого дослідження - фокусгрупові дискусії з науково-педагогічними працівниками територіальних громад ІваноФранківщини та представниками інституцій, що забезпечують управління у сфері підвищення якості надання післядипломних освітніх послуг.

Метою проведення нашого фокус-групового дослідження $є 3$ одного боку з'ясування думок та вивчення проблем, потреб педагогічних працівників початкової школи територіальних громад із врахуванням їх особистісних якостей, середовища, в якому відбувається конкретний освітній процес. А оскільки належна організація підвищення рівня освіти педагогів територіальних громад неможлива без застосування інструментів зворотного зв'язку та узгодження отриманих відповідей з управлінськими кроками посадовців, що і виступило іншим боком фокус-групового дослідження.

I фокус-група - вчителі шкіл територіальних громад Івано-Франківщини (8-10 осіб).

II фокус-група - управлінці освітньої галузі Івано-Франківщини (8-10 осіб: представники відділу освіти, закладів підвищення кваліфікації, дирекції шкіл).

Тривалість фокус-групових засідань - від 1 год. 30 хв. до 2 год.

Інструментарій:

Сценарій (гайд) I фокус-групової дискусії за методом напівструктурованого інтерв'ю:

Вступна частина: знайомство $з$ учасниками дискусії, окреслення мети дослідження, узгодження умов участі, погодження конфіденційності та згоди респондентів на запис інтерв'ю.

Основна змістова частина:

- Розкажіть, будь ласка, про свою роботу: як давно Ви працюєте (Ваш педагогічний стаж), що стало причиною Вашого професійного вибору, тощо?

- Поділіться Вашим досвідом зростання рівня педагогічної майстерності, які використовуєте форми підвищення власної кваліфікації (наприклад: додаткові тренінги, навчання)?

- Чи задовольняє Вас система підвищення кваліфікації, яка склалася у школі?

- Чи враховуються та вивчаються Ваші потреби в підвищенні рівня науково-теоретичної та психологічної підготовки? Якщо так, то в якій формі це відбувається?

- Чи вмотивовує Вас система підвищення кваліфікації у подальшому до самовдосконалення та до самоосвіти?

- Які форми методичної роботи в школі вважаєте найбільш ефективними?

- На Ваше переконання, чи достатньо забезпечена шкільна бібліотека сучасною методичною, науковою, науково-методичною літературою? Чи є в бібліотеці спеціалізовані видання (преса і книги) для вчителів?

- Чи інформатизована школа, чи має відповідне комп'ютерне забезпечення?

- Від чого, на Вашу думку, залежить якість освіти вчителів передовсім?

- Які Ви бачите основні ресурси поліпшення якості освіти педагогів?

- Чи Ви бачите різницю в доступі до освіти місцевих вчителів та вчителів територіальних громад? Яку саме?

Заключна частина: підбиття підсумків, уточнення відповідей, доповнення, дискусія, коментарі, подяки. 
Сценарій (гайд) II фокус-групової дискусії за методом напівструктурованого інтерв'ю:

Вступна частина: знайомство з учасниками дискусії, окреслення мети дослідження, узгодження умов участі, погодження конфіденційності та згоди респондентів на запис інтерв'ю.

Основна змістова частина:

- Розкажіть, будь ласка, про свою роботу (яка Ваша роль в освітньому процесі), що стало причиною Вашого професійного вибору, тощо?

- Від чого, на Вашу думку, залежить якість освіти вчителів передовсім?

- Чи відповідає, на Вашу думку, система підвищення кваліфікації, яка склалася в державі, освітнім потребам та запитам вчителів?

- Яким чином урівноважити значущість ролі вчителя початкових класів 3 реальним рівнем престижності цієї професії? Хто і що саме, на Ваше переконання, повинен зробити задля підвищення рівня престижності професії вчителя?

- Чи враховуються потреби педагогічних працівників у підвищенні рівня їх науковотеоретичної та психологічної підготовки? Якщо так, то в якій формі відбувалося вивчення цих потреб?

- Які Ви бачите основні ресурси поліпшення якості освіти педагогів?

- Чи Ви бачите різницю в доступі до освіти місцевих вчителів та вчителів територіальних громад? Яку саме?

Заключна частина: підбиття підсумків, уточнення відповідей, доповнення, дискусія, коментарі, подяки.

Результати дослідження.

I фокус-група. Кількість респондентів - 8 осіб. За типом професійної кваліфікації - вчителі початкової школи.

Під час I фокус-групової дискусії важливим було визначити, як респонденти оцінюють умови підвищення професійної кваліфікації, які склалися в державі, та чи вважають вони, що освітні можливості в сфері підвищення кваліфікаційної підготовки є рівними (незважаючи на місце проживання, вік чи інші чинники), якщо ні, тоді як саме ці умови вони пропонують урівноважити.

Загалом, відповіді засвідчили, що педагоги регулярно підвищують професійні компетентності: проходять курси підвищення кваліфікації, відвідують тренінги, вебінари, діляться досвідом 3 колегами, займаються самоосвітою та інше. Респондентка зауважила: "B час карантину всі курси проводяться онлайн $і$ вони більш зосереджені на подачу теоретичного матеріалу, а нам десь не вистачає практичного вдосконалення та й живого спілкування 3 нашими методистами бракує”.

Вчителі поділилися інформацією у яких заходах з підвищення професійної кваліфікації взяли участь останнім часом, серед них: куси НУШ, курси “Smart kids”, пілотний проєкт сертифікації вчителів початкової школи, онлайнкурси Prometheus, онлайн-курси EdEra та інші. Важливо, що серед перелічених не тільки ті, які пропонує відділ освіти, але й ті, у яких вчителі взяли участь $з$ власної ініціативи.

На запитання, чи достатньо забезпечена шкільна бібліотека сучасною методичною, науковою, науково-методичною літературою відповідь була одноголосною: “З часу функціонування НУШ у школах є достатньо літератури, проте про засоби унаочнення, роздатковий матеріал повинен турбуватися вчитель”.

Педагогічні працівники свою професію вважають престижною. Як вони зауважили: "Про престиж нашої прачі засвідчуе повага від батьків та учнів".

Та все ж тут простежується проблемний момент - це недостатня оплата праці: “Ми тепер стали ближчими до європейських країн, мали можливість побувати за кордоном, порівнюючи розуміємо, щзо було б добре, якби в Україні заробітна плата відповідала корисності даної професії".

Урівноваження означеного фактора на суспільному рівні може виступити рушійною силою вмотивування постійного професійного зростання.

Учителі наголосили й на тому, що вони активно займаються самоосвітою та самовдосконаленням. Зазначили, що: “... саме завдяки самостійному оволодінню навичками використання циифрових засобів змогли дистанційно навчати своїх учнів".

Щодо запитання про те, чи враховуються потреби педагогічних працівників у підвищенні рівня їх науково-теоретичної та психологічної підготовки? Якщо так, то в якій формі відбувалося вивчення цих потреб відповідь була неоднозначна. Одні запевнили: “... потреби вивчаються під час заповнення анкет на кусах, де збирається відповідний діагностичний матеріал”, проте інші зауважили: “... варто, щзоб ці питання вивчалися більш глибоко та часто, можливо на рівні шкіл $і$ для цього варто запровадити вивчення освітніх потреб не тільки відповідно до їх кваліфікаційного рівня а й з урахуванням особистісної сфери інтересів".

Основними перешкодами рівного доступу до підвищення освітнього рівня вчителі вважають: 
- обмежений доступ до Інтернету, або ж неякісний Інтернет: “B корпусі нашої початкової школи ще досі немає інтернету, а до іншого корпусу - метрів 300”;

- недостатня поінформованість про додаткові можливості підвищення кваліфікації: “Було б добре, якби функиіонувала певна єдина платформа за допомогою якої можна було б дізнатися про різні можливості підвищення кваліфікації”;

- слабка вмотивованість до професійного вдосконалення. Тут респондентка відзначила: "після проходження курсів почуваюся більи зацікавлено в самоосвіті, а вже через певний період часу мотивації не вистачає”.

Звідси випливає, що одне із основних завдань курсів підвищення кваліфікації полягає у виробленні у вчителів внутрішньої потреби кваліфікаційного зростання як основи їх пізнавально-творчої активності шляхом створення атмосфери необхідності, зацікавленості та особистої відповідальності.

II фокус-група. Кількість респондентів - 6 осіб. За типом професійної кваліфікації - завідувач відділу освіти (1), методист (1), директор школи (2), заступник директора з навчальної роботи (2).

Під час II фокус-групової дискусії 3 управлінцями ми мали на меті конкретизувати, від чого насамперед залежить якість освіти вчителів початкової школи, які основні ресурси поліпшення якості їх освіти та як врівноважити умови підвищення кваліфікації вчителів територіальних громад Івано-Франківщини.

Респонденти зазначили, що якість освіти педагогів залежить від багатьох факторів, а саме:

- самоосвіти: “самоосвіта - ие та ланка освіти, до якої мають доступ всі...”;

- креативності: “творчий вчитель маючи тільки комп 'ютер та принтер зможе зробити свої уроки иікавими та незабутніми”;

- підтримки адміністрації школи, технічного забезпечення;

- післядипломної освіти: “вчителі повинні відвідувати різні курси, не тільки ті, які пропонують інститути післядипломної освіти";

- вимог держави: “особливий вплив на якість освіченості мають вимоги, які висуває суспільство до педагогічних працівників”.

Під час розгляду питання про різницю в доступі до освіти місцевих вчителів та вчителів територіальних громад, зафіксовано такі проблемні моменти: “немає стабільного моніторингу потреб педагогічних прачівників y підвищенні їх рівня науково-теоретичної та психологічної підготовки”, “нерівні умови nраці” (тут респонденти вели мову про матеріальне забезпечення міських та сільських шкіл).

Під час дискусії щодо врівноваження значущості ролі вчителя початкових класів 3 реальним рівнем престижності цієї професії, освітяни відповіли: “.. в даному випадку ініиіатива повинна йти насамперед від органів влади на державному рівні”. “Органи влади у сфері освіти повинні звернути увагу на те, щзо молоді вчителі не заохочені працювати в школі у зв'язку із низькою заробітною платою”. "Але і вчитель не може залитатися осторонь, тому: повинен бути авторитетний, “іти в ногу з часом”, всесторонньо розвиватися, володіти методикою викладання, вміти співпрацювати як із учнями так $i$ з батьками своїх вихованців, а також бути добре обізнаний із системою інклюзивної освіти”.

Якщо вищеперелічені чинники будуть діяти синхронно, звісно, престижність праці вчителя займе гідну позицію.

Обмеження дослідження: оскільки фокусгрупові дискусії відбувалися онлайн, поза межами участі в емпіричній частині дослідження залишились ті педагогічні працівники, які не мають доступу до мережі Інтернет, або не забезпечені цифровими засобами спілкування.

\section{Висновки та рекомендації:}

У рамках проведеного дослідження, пропонуємо на розгляд наукового співтовариства практичні рекомендації, спрямовані на удосконалення освітніх політик для працівників територіальних громад, сформульовані нами за підсумками дослідження, спрямованого на вивчення освітніх політик регіонального рівня задля забезпечення рівного доступу до освітніх можливостей для всіх категорій науковопедагогічних працівників початкової школи. На наше переконання, задля ефективного впровадження на регіональному рівні, такі рекомендації мають бути адресовані трьом групам установ та організацій: по-перше, відділу освіти, директорам шкіл; по-друге, закладам підвищення кваліфікації; по-третє, методичним об'єднанням, школам передового досвіду.

Відділу освіти, директорам шкіл:

- лобіювати процеси адаптації законодавства відповідно до значущості ролі вчителя початкових класів та реальним рівнем престижності цієї професії (гідна оплата праці, забезпечення проходження стажування не тільки у вітчизняних закладах, а й за кордоном [7]); 


\section{ПОКРАЩЕННЯ ПОЛТИК РІВНОГО ДОСТУПУ ДООСВІТНІХ МОЖЛИВОСТЕЙ ВЧИТЕЛІВ ПОЧАТКОВОЇ ШКОЛИ ТЕРИТОРІАЛЬНИХ ГРОМАДІВАНО-ФРАНКІВЩИНИ}

- готувати фахівців, спроможних захистити інтереси держави у жорстких умовах світової конкуренції (попереджати фактори, що можуть спричинити відтік кваліфікованих кадрів, сприяти розв'язанню проблеми юридичного визнання вітчизняних дипломів у країнах $(\mathrm{C})$;

- створити інфраструктурні та інші передумови доступності навчання для людей, які проживають у гірській місцевості, віддалених населених пунктах, та тих категорій населення, що потребують особливої уваги з огляду обмежених фізичних можливостей через впровадження механізму соціальної адресної підтримки 3 розширеннями пакету освітніх можливостей задля кращої доступності додаткової освіти;

- забезпечити зворотний зв'язок з працівниками через проведення внутрішніх опитувань з метою підвищення якості управлінських рішень, уточнення змістового наповнення програм стажувань, тощо.

Закладам підвищення кваліфікації:

- вмотивовувати, виробляти у вчителів внутрішню потребу кваліфікаційного вдосконалення як основу їх пізнавально-творчої активності шляхом створення обстановки й атмосфери необхідності, зацікавленості та особистої відповідальності, що зі свого боку уможливлює розвиток готовності освітян до позитивного професійного вдосконалення [див. наприклад: 5;17, 54-55];

- здійснювати гнучку кваліфікаційну підготовку, щоб фахівець міг легко перебудовуватися відповідно до мінливих вимог і мав можливість постійного професійного зростання (а саме, створити для вчителів лінію інформаційної та технічної підтримки);

- готувати викладачів курсів активними методами, щоб вони їх засвоювали i демонстрували учителям, а ті - своїм учням, що в майбутньому сприятиме обміну досвідом та ефективній діяльності освітян у суспільстві [див. наприклад: 4, 40];

Методичним об'єднанням, иколам передового досвіду:

- запровадити командне навчання, оскільки так формується спільне бачення прийдешності (кожен окремий педагог знатиме, навіщо, чого і як саме варто навчатися для спільного результату);

- забезпечити прозорість процесу підвищення освітнього рівня науково-педагогічних працівників, а саме, освітяни повинні мати внутрішне відчуття психологічної безпеки (із можливістю вільно висловлювати свої думки, не боячись бути висміяними чи критично оціненими);

- впровадити гнучкість у процесі навчання, яке має бути запроектованим досконало, але трактувати його слід еластично (інколи потрібно обговорити щось детальніше і довше, а від чогось взагалі відмовитися);

- запровадити вивчення освітніх потреб науково-педагогічних працівників відповідно не тільки до їх кваліфікаційного рівня, а ще й із врахуванням сфери інтересів;

- формувати фахівця, здатного вільно й широко мислити, створювати інтелектуальні цінності [19], яких потребують суспільство взагалі і школа зокрема (створити можливість педагогічним працівникам вибирати напрям підвищення кваліфікації відповідно до сфери фахових інтересів).

Відомо, що в сучасних прискорених темпах розвитку науки і техніки, вчителі освітніх закладів не можуть стояти на місці і використовувати тільки знання, отримані у закладі вищої освіти. Сьогодні вчитель повинен бути універсальним. Адже, хто як не він зможе розв'язати суперечність між реальним змістом педагогічної освіти, вимогами школи і викликами держави.

\section{ЛIТЕРАТУРА}

1. Аналіз освітньої політики: теорія і практика управління на місцевому рівні: наук. посіб. / авт. кол.: В. Базілюк, Т. Бойченко, Л. Забродська; Держ. вищ. навч. заклад “Ун-т менедж. освіти”. Київ: Вид-во ДВНЗ “Ун-т менеджменту освіти” НАПН України, 2014. 306 с. URL: https://lib.iitta.gov.ua/8108/1/\%D0\%B0\%D0\%BD\% D0\%B0\%D0\% BBi\%D0\%B7_\% D0\%BE\%D1\%81\%D $0 \% \mathrm{~B} 2 \mathrm{i} \% \mathrm{D} 1 \% 8 \quad 2 \% \mathrm{D} 0 \% \mathrm{BD} \% \mathrm{D} 0 \% \mathrm{BEi} \% \mathrm{D} 0 \% \mathrm{BF}$ $\% \mathrm{D} 0 \% \mathrm{BE} \% \mathrm{D} 0 \% \mathrm{BBi} \% \mathrm{D} 1 \% 82 \% \mathrm{D} 0 \% \mathrm{~B} 8 \% \mathrm{D} 0 \% \mathrm{BA} \% \mathrm{D} 0 \% \mathrm{~B} 8 \mathrm{pdf}$

2. Бачинська $€$. Вектори змін методичної роботи в закладах загальної середньої освіти в контексті реформування освіти в Україні. Народна освіта. 2017. Вип. 3. С. 16-21. URL: http://nbuv.gov.ua/UJRN/ NarOsv_2017_3_5

3. Дослідження щодо забезпечення підготовки педагогічних працівників. Training Assessment Project. 2021. URL: https://mon.gov.ua/ua/news/trivaye-spilnedoslidzhennya-shodo-zabezpechennya-pidgotovkipedagogichnih-pracivnikiv-training-assessment-project

4. Дзежговська I. Навчання вчителів: підручник для викладача-тренера. Львів : Літопис, 2002. 173 с.

5. Дудар 3., Ревенчук І. Проблеми і перспективи післядипломної освіти в Україні. Вища школа. 2009. № 5. C. $111-118$.

6. Клокар Н. Диференційований підхід до підготовки вчителів у системі післядипломної педагогічної освіти. Шлях освіти. 2006. С. 41-44.

7. Ковальчук В. Професійний розвиток вчителів: зарубіжний досвід. Освітня політика. 2015. URL: http:/ leducation-ua.org/ua/porivnyalna-pedagogika/485profesijnij-rozvitok-uchiteliv-zarubizhnij-dosvid

8. Матвеєва Н. Організація науково-методичної роботи 3 учителями початкової загальноосвітньої 


\section{ПОКРАЩЕННЯ ПОЛТИК РІВНОГО ДОСТУПУ ДО ОСВІТНІХ МОЖЛИВОСТЕЙ ВЧИТЕЛІВ ПОЧАТКОВОЇ ШКОЛИ ТЕРИТОРІАЛЬНИХ ГРОМАД ІВАНО-ФРАНКІВЩИНИ}

школи в Україні (1945-1990 рр.) : дис. ... канд. пед. наук: 13.00.01 / Прикарпатський національний університет ім. Василя Стефаника. Івано-Франківськ, 2009. 288 с

9. Михайлишин Р. Професійно-педагогічна культура учителів початкових класів. Вісник Львівського університету. 2012. № 28. С. 25-34.

10. Моніторинг інтеграції української системи вищої освіти в Європейський простір вищої освіти та наукового дослідження: моніторинг. дослідж. : аналіт. звіт / Міжнарод. благод. фонд "Міжнарод. фонд дослідж. освіт. політики"; за заг. ред. Т.В. Фінікова, О.І. Шарова. Київ: Таксон, 2014. - 144 c. URL: https://kvit.ukma.edu.ua/ wp-content/uploads/2015/01/\%d0\%90\%d 0\%bd $\% \mathrm{~d} 0$

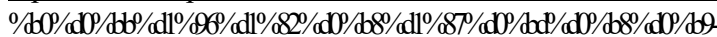
$\% \mathrm{~d} 0 \% \mathrm{~b} 7 \% \mathrm{~d} 0 \% \mathrm{~b} 2 \% \mathrm{~d} 1 \% 96 \% \mathrm{~d} 1 \% 82 . \mathrm{pdf}$

11. Навчати і навчатися: як і куди зростати українському вчительству? Результати дослідження сфери підвищення кваліфікації й сертифікації у рамках спільної ініціативи руху EdCamp Ukraine i MOH України / О. Елькін, О. Марущенко, О. Масалітіна, І. Міньковська Херсон: “Дім Реклами”, 2019. - 120 с. URL: https:// docs.wixstatic.com/ugd/df4ebb_efe324089d57 4e64af649 $18 \mathrm{~b} 415015 \mathrm{c}$ d.pdf?fbcl id=IwAR3xpgr 8vuGm7wo3 KmlwJDanh1KjQAnIJTZp8A6xFqo7bIY2796SQd0CkRw

12. Ніколасску I. Роль інститутів післядипломної освіти в розвитку культуротворчої особистості педагога. Науковий вісник Ужгородського національного університету. 2013. № 26. С. 136-139.

13. Носовець Н. Професійна підготовка майбутніх учителів у країнах Західної Свропи. Вісник. 2015. № 130 C. 68-72. URL: http://erpub.chnpu.edu.ua:8080/jspui/ bitstream/123456789/2338/1

14. Овчарук О., Іванюк І. Результати онлайн опитування "Потреби вчителів у підвищенні фахового рівня з питань використання цифрових засобів та IКТ в умовах карантину" : аналітичні матеріали. Київ : IITЗН НАПН України. 2020. 25 c. https://lib.iitta.gov.ua/719908

15. Олійник В. Проблеми та шляхи розвитку системи післядипломної педагогічної освіти України в сучасному полікультурному суспільстві. Вища освіта України. 2009. № 4. С. 24-34.

16. Приймакова В. Розвиток післядипломної освіти вчителів початкових класів в Україні (1948-2012 pp.) дис. ... д-ра пед. наук : 03.00.01 / Херсонська академія неперервної освіти. Херсон, 2016. 487 c. URL: http:// dspace.tnpu.edu.ua/bitstream/123456789/6408/1/ Prymakova.pdf

17. Пуховська Л., Артюшина М., Базелюк В., Лушин П., Снісаренко О., Сніцар Л., Солодков В. Післядипломна освіта в умовах євроінтеграції : сутність, зміст технології, готовність до змін: навчально-методичний посібник / за наук. ред. Л. Пуховської. Київ : Педагогічна думка, 2012. $122 \mathrm{c}$.

18. Реформа освіти в Україні. Місячний звіт №8 від 17 лютого 2013 Проєкт "Популярна економіка : моніторинг реформ”. URL: http://www.eba.com.ua/static/ members.../Case_Study_17_02_2013_UKR.pdf

19. Ромадіна Л. Діагностика праці вчителя. Osvita.ua: веб-сайт. 2008. URL: https://osvita.ua/school/ method/649/

20. Скульський Р. Розвиток та використання творчого потенціалу освітян у науково-методичній роботі. Тенденції розвитку методичної роботи в системі післядипломної освіти педагогів : матеріали Всеукр. наук.-практ. конф. 2003. С. 55-59.

21. Стратегія реформування освіти в Україні : Рекомендації з освітньої політики. Київ: К.І.С., 2003.296 с. URL: https://www.irf.ua/files/ukr/programs_edu ep_409_ua_ref_strategy.pdf

22. Терещенко А. Моделювання процесу формування організаційної культури майбутнього вчителя початкових класів. Scientific Journal “ScienceRise” № $12 / 5$ (17) 2015. C. 17-21.URL: https://www.researchgate.net/publication/ 288855557

23. Тимчук Л. Становлення та розвиток андрагогіки як теорії і практики освіти дорослих в Україні (кінець XIX-XX століття) : дис. ... д-ра пед. наук : 13.00.01 / Чернівецький національний університет імені Юрія Федьковича. Чернівці, 2016. 496 c. URL: http:// dspace.tnpu.edu.ua/bitstream/123456789/6313/1/ Tymchuk.pdf

\section{REFERENCES}

1. Analiz osvitnoi polityky: teoriia i praktyka upravlinnia na mistsevomu rivni: nauk. posib. (2014). [The analysis of educational politic: theory and practice of management on local level: scientific manual]. (Ed.). Baziliuk, V. \& Boichenko, T. 306 p. Available at: https:// lib.iitta.gov.ua/ $8108 / 1 / \%$ D $0 \%$ B 0 \% D 0\%BD $\% \mathrm{D} 0 \% \mathrm{~B} 0 \% \mathrm{D} 0 \% \mathrm{BBi} \% \mathrm{D} 0 \% \mathrm{~B} 7$ \%D0\%BE\%D1\% $81 \% \mathrm{D} 0 \%$ B2i\%D1\%82 \%D0\%BD \%D0 \%BEi \%

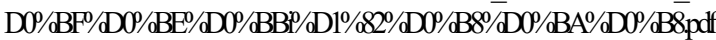
[in Ukrainian].

2. Bachynska, Ye. (2017). Vektory zmin metodychnoi roboty $\mathrm{v}$ zakladakh zahalnoi serednoi osvity $\mathrm{v}$ konteksti reformuvannia osvity $\mathrm{v}$ Ukraini [Vector of change of methodological work in general secondary education institution in the context of educational reform in Ukraine]. Public education. Vol. 3. pp. 16-21. Available at: http:// nbuv.gov.ua/UJRN/NarOsv_2017_3_5 [in Ukrainian].

3. Doslidzhennia shchodo zabezpechennia pidhotovky pedahohichnykh pratsivnykiv (2021). [Study on the preparation of teacher training]. Training Assessment Project. Available at: https://mon.gov.ua/ua/news/trivayespilne-doslidzhennya-shodo-zabezpechennyapidgotovki-pedagogichnih-pracivnikiv-trainingassessment-project [in Ukrainian].

4. Dzezhhovska, I. (2002). Navchannia vchyteliv: pidruchnyk dlia vykladacha-trenera [Teachers teaching: teacher trainer's manual]. Lviv, 173 p. [in Ukrainian].

5. Dudar, Z. \& Revenchuk, I. (2009). Problemy i perspektyvy pisliadyplomnoi osvity v Ukraini [Problems and perspectives of post-graduate education in Ukraine]. High school. No. 5. pp. 111-118. [in Ukrainian].

6. Klokar, N. (2006). Dyferentsiiovanyi pidkhid do pidhotovky vchyteliv u systemi pisliadyplomnoi pedahohichnoi osvity [Differentiated approach to teacher training in the system of post-graduate education]. The path of education. pp. 41-44. [in Ukrainian].

7. Kovalchuk, V. (2015). Profesiinyi rozvytok vchyteliv: zarubizhnyi dosvid [Teachers' professional development: intercultural experience]. Educational policy. Available 


\section{ПОКРАЩЕННЯ ПОЛІТИК РІВНОГО ДОСТУПУ ДО ОСВІТНІХ МОЖЛИВОСТЕЙ ВЧИТЕЛІВ ПОЧАТКОВОӤ ШКОЛИ ТЕРИТОРІАЛЬНИХ ГРОМАД ІВАНО-ФРАНКІВЩИНИ}

at: http://education-ua.org/ua/porivnyalna-pedagogika/ 485-profesijnij-rozvitok-uchiteliv-zarubizhnij-dosvid [in Ukrainian].

8. Matveieva, N. (2009). Orhanizatsiia naukovometodychnoi roboty $\mathrm{z}$ uchyteliamy pochatkovoi zahalnoosvitnoi shkoly v Ukraini (1945-1990 rr.) [Organization of scientific and methodical work with teachers of primary school in Ukraine (1945-1990)]. Candidate's thesis. Ivano-Frankivsk, 288 p. [in Ukrainian].

9. Mykhailyshyn, R. (2012). Profesiino-pedahohichna kultura uchyteliv pochatkovykh klasiv [Primary school teachers' professional-pedagogical culture]. Bulletin of Lviv University. No. 28. pp. 25-34. [in Ukrainian].

10. Monitorynh intehratsii ukrainskoi systemy vyshchoi osvity v Yevropeiskyi prostir vyshchoi osvity ta naukovoho doslidzhennia (2014). [Control over the Ukrainian higher education system integration in European space of higher education and academic study: monitor research: analytical report]. International Charity Foundation "International fund of research of education. policies; (Ed.). Finikova, T. \& Sharova, O. Kyiv, 144 p. Available at: https://kvit.ukma.edu.ua/wp-content/ uploads $/ 2015 / 01 / \% \mathrm{~d} 0 \% 90 \% \mathrm{~d} 0 \% \mathrm{bd} \% \mathrm{~d} 0 \% \mathrm{~b} \quad 0 \% \mathrm{~d} 0 \% \mathrm{~b}$ b\%d1\%96\%d1\%82\%d0\%b8\%dl\%87\%d0\%bd\%d0\%b8\%d0\%b9$\% \mathrm{~d} 0 \% \mathrm{~b} 7 \% \mathrm{~d} 0 \% \mathrm{~b} 2 \% \mathrm{~d} 1 \% 96 \% \mathrm{~d} 1 \% 82 . p d f[$ in Ukrainian].

11. Navchaty i navchatysia: yak i kudy zrostaty ukrainskomu vchytelstvu? Rezultaty doslidzhennia sfery pidvyshchennia kvalifikatsii y sertyfikatsii u ramkakh spilnoi initsiatyvy rukhu EdCamp Ukraine i MON Ukrainy (2019). [Teach and learn: how and where should Ukrainian teaching grow? The results of exploration the sphere of advanced training and certification as part of overall initiative of EdCamp Ukraine and Ministry of Education and Science of Ukraine]. Elkin, O., Marushchenko, O., Masalitina, O. \& Minkovska, I. Kherson, 120 p. Available at: https://docs.wixstatic.com/ugd/df4ebb_efe324089d57 4e64af6491 8b415015cd.pd f?fbclid=IwA R3xpgr8v uGm7wo3KmlwJDanh1KjQAnIJTZp8A6xFqo7bIY2796SQd0CkRw [in Ukrainian].

12. Nikolaiesku, I. (2013). Rol instytutiv pisliadyplomnoi osvity v rozvytku kulturotvorchoi osobystosti pedahoha [The post-graduate institutions's role in the development of educator's cultural identity]. Scientific Bulletin of Uzhhorod National University. No. 26. pp. 136-139. [in Ukrainian].

13. Nosovets, N. (2015). Profesiina pidhotovka maibutnikh uchyteliv u krainakh Zakhidnoi Yevropy. [Future teachers' vocational training in Western Europe]. Bulletin. No. 130. pp. 68-72. Available at: http:// erpub.chnpu.edu.ua:8080/jspui/bitstream/123456789/2338/ 1 [in Ukrainian].

14. Ovcharuk, O. \& Ivaniuk, I. (2020). Rezultaty onlain opytuvannia "Potreby vchyteliv u pidvyshchenni fakhovoho rivnia $\mathrm{z}$ pytan vykorystannia tsyfrovykh zasobiv ta IKT v umovakh karantynu": analitychni materialy [The results of online survey "Teachers' needs in increasing of professional level concerning usage of digital tools and ICT under quarantine" analytical materials]. Kyiv, 25 p. Available at: https://lib.iitta.gov.ua/ 719908/[in Ukrainian].

15. Oliinyk, V. (2009). Problemy ta shliakhy rozvytku systemy pisliadyplomnoi pedahohichnoi osvity Ukrainy v suchasnomu polikulturnomu suspilstvi [Problems and ways of developing Ukrainian post-graduation pedagogical education in modern multicultural society]. Higher education in Ukraine. No. 4. pp. 24-34. [in Ukrainian].

16. Pryimakova, V. (2016). Rozvytok pisliadyplomnoi osvity vchyteliv pochatkovykh klasiv v Ukraini (19482012 rr.) [Development of postgraduate education of primary school teachers in Ukraine (1948-2012)]. Doctor's thesis. Kherson, 487 p. Available at: http:// dspace.tnpu.edu.ua/bitstream/123456789/6408/1/ Prymakova.pdf [in Ukrainian].

17. Pukhovska, L., Artiushyna, M., Bazeliuk, V., Lushyn, P., Snisarenko, O., Snitsar, L. \& Solodkov, V. (2012). Pisliadyplomna osvita $\mathrm{v}$ umovakh yevrointehratsii: sutnist, zmist, tekhnolohii, hotovnist do zmin [Postgraduation education in European integration: idea, content, techniques, availability to change]. Educationalmethodological manual. (Ed.). Pukhovskoi, L. Kyiv, 122 p. [in Ukrainian].

18. Reforma osvity v Ukraini (2013). [Educational reform in Ukraine]. Monthly Report №8 of February 17, 2013 "Popular Economy Project: Monitoring Reforms". Available at: http://www.eba.com.ua/static/members.../ Case_Study_17_02_2013_UKR.pdf

19. Romadina, L. (2008). Diahnostyka pratsi vchytelia [Teacher's work diagnosis]. Available at: https://osvita.ua/ school/method $/ 649 /$ [in Ukrainian].

20. Skulskyi, R. (2003). Rozvytok ta vykorystannia tvorchoho potentsialu osvitian u naukovo metodychnii roboti [Development and use of creative potential of educators in scientific and methodical work]. Tendentsii rozvytku metodychnoi roboty $v$ systemi pisliadyplomnoi osvity pedahohiv : materialy Vseukr. nauk.-prakt. konf. - Trends in the development of methodological work in the system of postgraduate education of teachers: Proceedings All-Ukrainian. Scientific-Practical Conference. pp. 55-59. [in Ukrainian].

21. Stratehiia reformuvannia osvity v Ukraini: rekomendatsii z osvitnoi polityky (2003). [The strategy of education reform in Ukraine: educational politic guidance]. Kyiv, 296 p. Available at: https://www.irf.ua/files/ukr/ programs_edu_ep_409_ua_ref_strategy.pdf [in Ukrainian].

22. Tereshchenko, A. (2015). Modeliuvannia protsesu formuvannia orhanizatsiinoi kultury maibutnoho vchytelia pochatkovykh klasiv [Future primary teacher' organization culture modelling process]. Scientific Journal "ScienceRise"No. 12/5 (17) pp. 17-21. Available at: https:/ /www.researchgate.net/publication/288855557 [in Ukrainian].

23. Tymchuk, L. (2016). Stanovlennia ta rozvytok andrahohiky yak teorii i praktyky osvity doroslykh v Ukraini [Establishment and development of andragogy like theory and practice of adult education in Ukaine (ending XIX-XX century)]. Doctor's thesis. Chernivtsi, 496 p. Available at: http://dspace.tnpu.edu.ua/bitstream/ 123456789/6313/1/Tymchuk.pdf [in Ukrainian].

Стаття надійшла до редакції 02.12.2021 